\title{
The Signalling Value of Education across Genders
}

\author{
Nielsson, Ulf; Steingrimsdottir, Herdis
}

Document Version

Accepted author manuscript

\section{Published in:}

Empirical Economics

DOI:

10.1007/s00181-017-1264-z

Publication date:

2018

License

Unspecified

Citation for published version (APA):

Nielsson, U., \& Steingrimsdottir, H. (2018). The Signalling Value of Education across Genders. Empirical Economics, 54(4), 1827-1854. https://doi.org/10.1007/s00181-017-1264-z

Link to publication in CBS Research Portal

\section{General rights}

Copyright and moral rights for the publications made accessible in the public portal are retained by the authors and/or other copyright owners and it is a condition of accessing publications that users recognise and abide by the legal requirements associated with these rights.

Take down policy

If you believe that this document breaches copyright please contact us (research.lib@cbs.dk) providing details, and we will remove access to the work immediately and investigate your claim. 


\title{
The Signalling Value of Education across Genders Ulf Nielsson and Herdis Steingrimsdottir
}

\author{
Journal article (Accepted version*)
}

\section{Please cite this article as:}

Nielsson, U., \& Steingrimsdottir, H. (2018). The Signalling Value of Education across Genders. Empirical Economics, 5414), 1827-1854. https://doi.org/10.1007/s00181-017-1264-z

This is a post-peer-review, pre-copyedit version of an article published in Empirical Economics. The final authenticated version is available online at:

DOl: https://doi.org/10.1007/s00181-017-1264-z

* This version of the article has been accepted for publication and undergone full peer review but has not been through the copyediting, typesetting, pagination and proofreading process, which may lead to differences between this version and the publisher's final version AKA Version of Record.

Uploaded to CBS Research Portal: September 2019 


\title{
The signalling value of education across genders
}

Ulf Nielsson
Herdis Steingrimsdottir*

March 2017

\begin{abstract}
This study examines gender discrimination and the possibility that education is more important for signalling ability among women than men. As social networks tend to run along gender lines and managers in the labour market are predominantly male, it may be more difficult for women to signal their ability without college credentials. The Lang and Manove (2011) model of racial discrimination and educational sorting is applied to examine the gender gap in schooling attainment. The model is empirically estimated for whites, blacks and Hispanics separately, with the results among whites consistent with education being more valuable to women due to signalling. For $90 \%$ of the whites in the sample women choose a higher level of education, given their ability, than men. Women on average obtain 0.5-0.7 extra years of schooling compared to men with the same ability score.
\end{abstract}

JEL classification: I24, I26, J71

Keywords: Education, ability, signalling, gender, race

\footnotetext{
* Corresponding author. Herdis Steingrimsdottir, Copenhagen Business School, Department of Economics, 2000 Frederiksberg, Denmark, email: hs.eco@cbs.dk, tel.: +45 38153441. Ulf Nielsson, Copenhagen Business School, Department of Finance, email: un.fi@cbs.dk, tel.: +45 38152969.
} 


\section{Introduction}

Women's position in the labour market has changed considerably over the last decades.

Overall, the Western world has seen a growth in women's labour market participation and their relative wages. However, in recent years the growth in women's relative wages has been sluggish and uneven, the increase in female labour force participation reaching a plateau. In spite of increased labour market experience and educational attainment, a sizeable gender wage gap remains (see, e.g., Blau and Kahn, 2008; 2016).

In contrast to women's labour market outcomes, women's higher education has continued to grow. Since the early 1980s women have outnumbered men among new college graduates, the reverse gender gap increasing steadily since then. This development has introduced a previously unknown imbalance between the genders, confronting college admission officers with the question of whether to implement affirmative action for males to ensure campus diversity (Greene and Greene, 2004).

Considering recent trends in women's relative labour market outcomes, it is puzzling why women on average invest more in their human capital compared to men, since they are likely to spend more time out of the labour force and earn relatively less, given their educational attainment. It is also perplexing that women's wages are still lower than men's, even when differences in education and experience are accounted for. This paper contributes to the literature on the gender gap in wages and educational attainment by looking at whether the gap is consistent with a model of statistical discrimination and educational sorting, introduced by Lang and Manove (2011) (hereafter the LM model). The model could potentially simultaneously explain why women are more likely to attend and complete college than men, and why women are paid less than men, given their education and experience. 
Lang and Manove (2011) construct a game-theoretic model of educational signalling and statistical discrimination to explain why black males get more education than white males of similar cognitive ability. In their model employers do not perfectly observe productivity and, importantly, employers find it more difficult to evaluate the productivity of black job applicants than whites. However, employers' ability to evaluate productivity improves with the applicants' educational level. In this setting education has a signalling value, for black workers in particular. The model predicts that among those with intermediate levels of ability, blacks will have higher levels of education than whites, while the education levels should be similar for those with low and high levels of ability. The model furthermore predicts that when ability is not accounted for, the wages of blacks will be below the wages of whites with similar levels of education, but that the wages will be similar at low and high levels of ability.

In their paper Lang and Manove (2011) focus on racial discrimination and exclude women for most of their analysis, due to difficulties in handling differences in selection into the labour market. In this paper, we exploit various imputation techniques introduced in recent literature to tackle the important challenge of studying women's outcome in the labour market, and apply the LM model to study gender differences in wages and educational attainment. In line with the LM model we argue that employers find it more difficult to infer about the productivity about female workers than the productivity of male workers. As Lang and Manove (2011) and Arcidiacono et al. (2010) argue, productivity is less likely to be observable at lower levels of education when, e.g. college grades or college selectivity cannot be used to reveal information. Under these conditions, other aids such as networks, personal contacts and referrals can be of particular importance. That leaves groups that are inadequately represented in higher level positions at an informational 
disadvantage; as such, social networks are likely to run along gender and racial lines (see, e.g. Altonji and Blank, 1999; Hellerstein et al., 2008, Montgomery, 1991). Furthermore, the psychology and management literature finds that male managers are worse at evaluating female compared to male productivity (e.g., Hammer et al., 1974, Surmann, 1997, Bauer and Baltes, 2002). Several studies also document more egalitarian gender-role attitudes among individuals with higher levels of education (Cherlin and Walters, 1981; Thornton et al., 1983, Thornton and Freedman, 1979), which is why one may expect to find employers with more egalitarian views in the labour market for educated workers.

In their analysis, Lang and Manove (2011) focus on males and point out that looking at the wage outcomes of females is particularly difficult because of selection issues. Women's labour market participation is considerably lower than men's. In $2015,57 \%$ of women over 16 years old participated in the labour market, compared to $69 \%$ of men. Among 35-44 year olds, the participation rates are 74\% and 90\% (U.S. Department of Labor). Moreover, while men are usually assumed to positively select into the labour market, i.e. men with high wage potential are more likely to work, it is plausible that a mix of positive and negative selection exists for women. For example, equally productive women who are in different marriage markets may be subject to different selection rules. Women who are in a favourable marriage market have high reservation wages and select negatively into the labour market, while those who have poorer marriage market prospects select positively into work.

When studying gender differences in wages, it is important to take into consideration possible selectivity biases. Mulligan and Rubinstein (2008) show that the average selection rule among women has changed over time and that since the mid-1980s non-employed women on average have a lower earning potential than working women. Blau and Kahn 
(2006) also study the US gender gap and find that the gains in women's relative wages in the 1980 s were overstated, and that $25 \%$ of the convergence was due to changes in selection. Several selection correction methods have been used to get a better idea about the true gender gap in wages. In this paper we closely follow the method used by, e.g. Johnson et al. (2000), Neal (2004), and Olivetti and Petrangolo (2008). In other words, we use alternative imputation techniques that only require assumptions on whether the unobserved wages are below or above the median based on characteristics such as education, aid receipt and spousal income.

To study the predictions of the LM model for gender discrimination we use data from the National Longitudinal Survey of Youth 1979 (NLSY79), which is also used by Lang and Manove (2011). We compare educational decisions given ability scores (as measured by Armed Forces Qualification Test (AFQT)) and examine the returns to ability and schooling in terms of wages. The findings support the predictions of a signalling model in the labour market where employers' observations of women's productivity is noisier than that of men, but the precision of their observations improves with increased education of the worker. This creates an increased value of education for women, in particular for those of medium ability. Testing these model predictions, the data consistently show that women attain more schooling than men given their ability, especially at the intermediate levels of ability values. For $90 \%$ of the ability domain among whites, women choose a higher level of education, given their ability, than men do. The difference in educational attainment is maximised when the ability score is close to average, with women obtaining an additional 0.5-0.7 years of education compared to men with the same ability score. At the two extreme levels of ability, however, schooling levels across genders are more similar, as predicted by the model. 
The LM model applied to gender discrimination furthermore predicts that women receive relatively low wages for a given education level (particularly at the intermediate levels), when not controlling for ability. Since women have lower ability given their education (cf. previous result), they should on average receive lower compensation compared to men. We test this empirically by studying the relationship between earnings and education - using imputed wages to correct for selection in the labour market - and find that given education levels, there is a gender wage gap that corresponds to the ability differences that are not being accounted for. In sum, this result supports the prediction of the model by showing that women have lower wages than men with the same level of education - and that the gap is maximised at intermediate levels of education.

Finally, the model also predicts that women's wages are higher relative to men's wages at intermediate levels of ability when education is not controlled for. Our results are mixed but suggest overall that it is the case that women's wages are relatively higher at the intermediate levels.

The results lend support to the Lang and Manove's (2011) predictions when their model of racial discrimination is applied to gender differences among whites. Our findings are consistent with education being more valuable to women as a tool of signalling compared to men. We extend the analysis to look at two minorities, blacks and Hispanics. Existing research on the gender gap in educational attainment has paid surprisingly little attention to the stark differences in various demographic groups. A study by King (2006) reveals that the gender gap in college enrolment rates is widest among blacks, where $60 \%$ are women. In comparison, 55\% are women among Hispanic students and 55\% are women among whites. Moreover, the reverse gender gap in college enrolment is larger 
among students from lower income families. Among low income blacks, 68\% of those enrolled are female.

When estimating the LM model for blacks and Hispanics our results are nonconclusive (in contrast to those for whites). We do not find significant gender differences in college completion rates among Hispanics in our data, and our findings for blacks suggest that the educational gap across genders among blacks is explained by factors other than signalling. Although it is quite possible that both males and females in the minority groups benefit from the signalling value of education, relative to white males, it is less clear how the model of discrimination and signalling value applies when comparing two groups that are potentially discriminated against in the labour market. As such, our results offer a modest step towards filling the noticeable gap in the literature when it comes to gender discrimination among minority groups.

The remainder of this paper is divided up as follows: section 2 discusses the gender gap in wages and in college completion rates. Next, section 3 summarises the LM model and how the signalling effect of education may generate an increased incentive for women to obtain schooling. Section 4 then provides an overview of the data and section 5 presents the empirical analysis and results. Finally, section 6 concludes.

\section{Background}

\subsection{The gender gap in wages}

The gender wage gap has declined considerably over the last decades. The wage convergence was most pronounced in the 1980s but has since slowed down, leaving a significant wage gap behind. Noticeably, the gender gap has declined much more slowly at the top of the wage distribution than at the middle or the bottom (Blau and Kahn, 2016). 
Among possible explanations for the remaining gap are that women select into different occupations, industries and firms (Card et al, 2016; Levanon et al., 2009); and they work shorter hours and are more likely to experience labour market interruptions (Goldin, 2014; Bertrand et al., 2010, Noonan et al., 2005). Recent research suggests that conventional economic variables (such as non-labour or husband's income, education and demographic variables) fail to explain women's labour market participation and that female wage elasticities are becoming closer to male elasticities (See, Blau and Kahn, 2007 and Heim, 2007). This may indicate that women's attitudes towards the labour market and the role that it plays in their lives is becoming closer to that of men (Goldin, 2006; Blau and Kahn, 2007). This also suggests that it is becoming more important to consider the role of other factors in the gender wage gap, such as attitudes, preferences, non-cognitive skills and psychological attributes. For example, Santos-Pino (2012) finds that differences in selfconfidence may contribute to the gender pay gap, while other explanations, with mixed evidence, are differences in the desire to compete, the willingness to negotiate and the willingness to take risks (for reviews, see Bertrand, 2011; Croson and Gneezy, 2011).

Finally, there is evidence that at least some of the gender gap in wages reflects discrimination. Several studies find that women are less likely to be promoted (e.g. Addison et al., 2014; Gayle et al., 2012; Blau and DeVaro, 2007; Cobb-Clark, 2001; McCue, 1996). ${ }^{1}$ Furthermore, a number of recent studies have used experimental design to look at gender discrimination (e.g., Neumark, 1996; Goldin and Rouse, 2000; Moss-Racusin et al., 2012; Reuben, 2014; Correll et al, 2007) and all find evidence of gender discrimination in hiring. Moss-Racusin et al. (2012), who study how science faculty views and hires senior undergraduate students for a position as a science laboratory manager, find that male

${ }^{1}$ A noteworthy exception is a study by Hersch and Viscusi (1996) that finds that women are more likely to get promoted, since they on average start at lower level jobs. 
applicants were offered a starting salary that was almost USD 4,000 higher than comparable female applicants.

Lang and Manove (2011) and Arcidiacono et al. (2010) emphasise the argument that job discrimination may stem from the importance of networks, personal contacts and referrals in a labour market where productivity is not perfectly observable. Phelps (1972) and Lundberg and Startz (1983) introduced models of discrimination where employers are less capable of assessing the productivity of women and nonwhites, while Milgrom and Oster's (1987) seminal paper introduced the invisibility hypothesis, which states that when the job skills of disadvantaged workers (women and nonwhites) are not easily observed, firms will benefit from keeping these workers in low-level jobs. As a result, these workers are paid less on average and are less likely to be promoted than other workers with the same level of education and ability. Pinkston (2003) tests the predictions of these models empirically and finds strong evidence suggesting that employers are less able to evaluate the productivity signals of women compared to men. Another line of related research shows that women are more likely to advance when there are more women in top management (e.g. Kurtulus and Tomaskovic-Devey, 2012).

\subsection{The gender gap in higher education}

The female advantage in college enrolment and completion rates is by now a worldwide phenomenon, even among countries with relatively low gross domestic product levels. As early as $2003,57 \%$ of those enrolled in higher education in the US were females. Among undergraduates men made up $45 \%$ of students 24 years or younger and only $38 \%$ of those 25 or older, making women a sizable majority group (King, 2006). Complex, multidimensional factors are part of the explanation as to why women are beginning to 
outnumber men in higher education. For example, several studies reveal that cognitive and non-cognitive skills strongly predict scholastic attainment and wages (see, e.g. Heckman et al., 2006) since both of types of skills make the accumulation of human capital easier, lowering the non-monetary cost of schooling. Thus, a common explanation for the gender gap in college completion rates is that girls tend to outperform boys in high school and engage in behaviour that increases the likelihood of enrolling in college (see, e.g. Jacob, 2002; Buchman and Diprete, 2006). Similarly Becker et al. (2010) study gender differences in the distribution of non-cognitive skills by focusing on the standard deviation (rather than the mean), which is significantly higher for men - indicating that there are more men than women at the upper tail of the distribution. The demand for college graduates has grown (along with increased college earnings premium), shifting the cut-off point in the skill distribution to the left, attracting relatively more women than men to college.

Another segment in the literature focuses on the role of marginal returns to education and whether the greater economic benefits of college for women can explain the female college advantage (e.g. Goldin et al., 2006). Possible reasons for a higher college premium for women are that women are able to use education to escape gender discrimination in the labour market, or that uneducated men have more options and better access to more highly paid jobs compared to uneducated women. Chiappori et al.'s (2009) theoretical work likewise explains the gender differences in schooling in a model where labour-market returns to schooling are higher for women, which is supported by other studies that find the college premium is larger among women compared to men (e.g. Murphy and Welch; 1989, 1992; Card and DiNardo, 2002; Daugherty, 2005). For example, Jacob (2002) finds that the college premium accounts for approximately $40 \%$ of the gender gap in college completion. DiPrete and Buchman (2006), in contrast, find marginal returns to college to 
be higher for women than men, their results indicating that this does not suffice to explain the observed gender gap. Instead they find that the gap can be explained by a broader measure of wellbeing, including marriage outcomes, household standard of living and insurance against income deprivation. For instance, by studying family resources they find that parental education and the presence of the father have a significant effect on the gender gap in college completion rates.

Other studies question whether marginal returns of education are in fact higher among women. Peña (2006) presents evidence from Colombia, where women are more likely to obtain a college education but have lower marginal returns to education. Hubbard (2011) finds that when correcting for top code bias in the data there is no gender difference in the college wage premium. Thus other hypotheses exist as to why women have become more likely than men to attend college, including the Bill Gates syndrome, where men are more likely to be enticed by high-tech jobs that do not require college education, but also reasons such as men being more likely to be involved in gangs and crimes and because schools are increasingly female friendly, e.g. due to the increased female ratio in the teaching occupation.

Finally, a possible explanation is that, in line with Lang and Manove's (2011) arguments, employers' find it more difficult to assess the productivity of female workers in a male dominated labour market. In this case women may use education to replace networks and to signal their ability. ${ }^{2}$

\footnotetext{
${ }^{2}$ Lang and Manove (2011) thoroughly discuss the possibility that the educational gap between blacks and whites may stem from the difference in the quality of their schooling. Blacks are overrepresented in low quality schools, and underrepresented in high quality schools. To acquire a certain skill level, blacks need to obtain more schooling than whites, i.e. they substitute quality with quantity. In contrast, however, the share of females does not appear to vary with school quality (see, e.g. Autor et al., 2016 and Allensworth et al., 2016), which is why this is not a plausible explanation for the educational gap between males and females.
} 


\section{Modelling the signalling value of education}

Models of discrimination often argue that those who face prejudice in the labour market are less likely to invest in their human capital (see e.g. Lundberg and Startz, 1982; Coate and Loury, 1993). Recent papers examining black workers, however, suggest that the effect may in fact be in the opposite direction because education helps those who face discrimination to reveal their ability to potential employers (Lang and Manove, 2011; Arcidiacono et al., 2010). The idea that education is valuable as a tool to signal ability was first introduced within economics by Spence (1973). Combining this original idea of signalling with models of discrimination, the above-mentioned papers develop a framework to explain why, given ability, black men obtain more education than white men. Lang and Manove (2011) argue that the productivity of blacks is less easily observed than that of whites, but with increased education the ability of employers to evaluate productivity improves, until at sufficiently high educational levels the productivity for both groups is observed equally well. Arcidiacono et al. (2010) assume productivity signals are noisy for those with less education - both whites and blacks - but those signals become more accurate with increased education. However, as black men have lower ability (AFQT scores) on average, they are statistically discriminated against when productivity is not observable. In both of these frameworks, black workers have a bigger incentive than whites to invest in their human capital, given their ability.

This study applies the model introduced by Lang and Manove (2011) of educational attainment to examine gender differences in educational decisions. Whereas they focus on males and set separate parameters for black and white workers, based on the assumption that employers cannot observe the productivity of black workers in the same way as they 
can for white workers, we argue that a comparable assumption can be made across genders. ${ }^{3}$ Another fundamental assumption of the LM model is that the ability of employers to assess the productivity of black workers improves with the level of education, until reaching relatively high levels of education where productivity is observed equally well for both groups. The productivity of the highly educated may, e.g. be revealed or signalled by grades, college quality or informal networks. ${ }^{4}$

In the following we outline the main predictions of the LM model and refer the reader to Lang and Manove (2011) for proofs and a full description. The LM model has a continuum of workers of different ability levels, with ability a distributed over some fixed interval. Workers choose their level of schooling, where their strategy profile is described by a continuous and differentiable function, $S(a)$, which strictly increases in their ability, $a$. Workers' log productivity can be written as

$$
\ln p^{*}=q(s, a)+\varepsilon
$$

where $q(s, a)$ is a deterministic function of education and ability, $\varepsilon$ is a normal random variable with mean 0 and variance $\sigma_{\varepsilon}^{2}, q_{s s}<0$ (i.e. the marginal effect of education on productivity is diminishing) and $q_{s a}>0$ (i.e. ability complements schooling so the effect of schooling on productivity is higher for those of higher ability). The employer observes a worker's schooling, $s=S(a)$, and a signal of productivity $p$ given by

\footnotetext{
3 This follows from our previous discussion. To briefly reiterate, Montgomery (1991) shows that groups that are inadequately represented in higher-level positions may be at an information disadvantage. The psychology and management literature also reveals how male managers may be worse at evaluating female compared to male productivity (Hamner et al., 1974; Surmann, 1997; Bauer and Baltes, 2002). Furthermore social networks are likely to run along gender lines as well as racial lines, with referrals and personal contacts playing an important role in channeling information in the labour market (see Altonji and Blank, 1999).

${ }^{4}$ Moreover, as discussed above, more egalitarian gender-role attitudes among individuals with higher levels of education may result in employers with similar views in the educated labour market (Cherlin and Walters, 1981; Thornton et al., 1983; Thornton and Freedman, 1979), while networks may play a bigger role in the market for low-skill jobs, implying that a lack of network is more damaging at lower and intermediate educational levels (see Hellerstein, McInerney and Neumark, 2008).
} 


$$
\ln p=\ln p^{*}+u
$$

where $u$ is a random error with variance $\sigma_{u}^{2}$, which is continuous and decreasing in $s$. The random variables $\varepsilon$ and $u$ are assumed to be independently distributed. The observability of worker productivity can then by defined as

$$
\lambda(s) \equiv \frac{\sigma_{\varepsilon}^{2}}{\sigma_{\varepsilon}^{2}+\sigma_{u}^{2}(s)} \quad, \lambda(s) \in[0,1]
$$

To interpret, for a given $\sigma_{\varepsilon}^{2}>0$, suppose $\sigma_{u}^{2}(s)$ is large and therefore $\lambda(s)$ is close to 0 , then the employer's ability to directly observe worker productivity is poor. On the other hand if $\sigma_{u}^{2}(s)=0$ and $\lambda(s)=1$ then the employer observes productivity perfectly, in which case workers have no incentive to signal their productivity and will consequently obtain the efficient level of education.

The model provides the following key theoretical predictions:

i. If $S(a)$ describes any separating equilibrium of the workers' signalling game, then for all $a \in\left[a_{0}, a_{1}\right]$, where the interval $\left[a_{0}, a_{1}\right]$ is the support of worker abilities, we have that $S(a) \geq S^{*}(a)$, where $S^{*}(a)$ denotes the efficient level of education. This means that if productivity is observed perfectly then workers obtain the efficient level of education, $S^{*}(a)$. If, on the other hand, productivity is not observed perfectly then education has a signalling value and in equilibrium the level of schooling is always equal to, or above, the efficient level of education.

ii. Any well-behaved separating equilibrium, $S$, has the property that the education level, $S\left(a_{0}\right)$, of the lowest type of worker must be efficient and not influenced by signalling. In other words, there is no signalling value for the workers at the bottom of the ability distribution. This follows because $S(a)$ is strictly increasing in $a$, which 
implies that the employer will therefore always be able to infer that a worker with education, $S\left(a_{0}\right)$, has the lowest ability, $a_{0}$. As a result workers at the bottom of the ability distribution will not obtain any education above the efficient level of education, i.e. no extra education is obtained as it has no signalling value (i.e. the assumption of schooling being strictly increasing in ability leads employers to observe those with lowest ability as everyone else has a higher level of schooling).

iii. The ability of employers to observe workers' ability improves with the education level, $s$. Let $s^{*}$ be the lowest value of $s$ such that $\lambda(s)=1$ (i.e. such that employer observes worker productivity perfectly) for all $s \geq s^{*}$, and let $a^{*}=A\left(s^{*}\right)$. Then, for $a \geq a^{*}, S(a)$ is the same as in the case where information about productivity is perfect at all levels of education. This implies that there is no signalling value at the top end of the ability distribution, since for those workers ability is perfectly observed.

Intuitively the first key prediction means that at intermediate levels of ability, education is higher for those whose productivity is imperfectly observed, compared to those whose productivity is perfectly observed. In contrast, the latter two predictions imply that at the extremes of the ability distribution, there is no value of education as a productivity signal.

The predictions of the model can be summed up in the following corollaries:

COROLlaRY 1: (i) Women with low (except for the very lowest) or intermediate levels of ability obtain more education than their male counterparts. (ii) High ability women and very low ability women obtain the same levels of education as comparable males.

This follows directly from the model since education has signalling value for women, except at the extremes of the ability distribution. 
COROLLARY 2: Women receive relatively low wages for a given education level, particularly at the intermediate level.

It follows from Corollary 1 that, given their level of education, women have on average lower ability. Wages are increasing in both ability and education, which is why we expect them to have lower wages for a given level of education.

COROLLARY 3: Women receive relatively high wages for a given ability level, particularly at the intermediate level.

It follows from Corollary 1 that, given their level of ability, women have on average a higher level of education, which is why we expect them to have higher wages for a given level of ability.

\section{Data}

In the analysis we use data from NLSY79 in order to be able to compare our estimated parameters to those estimated by Lang and Manove (2011). Moreover, because the NLSY is a rich panel that includes information such as spousal income and public transfers, it is suitable for the use of various wage imputation techniques (e.g., Neal and Johnson, 1996, Johnson et al., 2000, and Neal, 2004). Since 1979 the Bureau of Labor Statistics has annually surveyed individuals born between 1957 and 1964 but has only conducted the surveys every other year since 1994. We use data through the 2000 wave of the survey, at which point the respondents are between 36 and 43 years of age.

Table 1, which summarises the statistics by race/ethnicity and gender, shows that women in the sample have higher college completion rates (16 years or more of schooling) than men among all groups. Women have higher mean AFQT scores than men among 
whites and blacks but not among Hispanics. For all groups, however, the standard deviation of AFQT scores is higher among men. Other variables shown in Table 1 also serve as control variables in the subsequent analysis. The key variables of interest from the survey are:

Education: Education is the highest grade completed as measured in number of years it took to obtain it. When regressions are performed at the individual level we look at the highest grade completed as of 2000 . When information is missing we use the information on highest grade completed from the 1998 and 1996 surveys. Observations where educational attainment is decreasing are excluded.

AFQT: The analysis proxies for ability using the AFQT score, which is standardised by age of the individual at the time the test is taken, such that for each age group, i.e. within each cohort, the mean test score is zero and the standard deviation equals one.

Weights: Sampling weights are used to make the results representative. We use the 2000 weight when available. For missing observations, we use 1996 and/or 1998 weights to obtain a predicted value of the 2000 weight.

Wages: The wage variable refers to the hourly rate of pay at the most recent job from the Current Population Survey section of the NLSY79 for those reported working. The hourly pay is updated using deflators from the 2011 Economic Report of the President. Observations where the real hourly rate of pay is less than USD1.00 or more than USD100 are dropped from the sample.

\subsection{Wages and selection into the labour market}

Since data on wages only exist for those who participate in the labour market, any comparison between the wages of men and women is subject to a selection bias (Heckman, 
1979, Gronau, 1974). Since labour market participation rates are lower among women than men, selection bias is more likely to be an issue when studying women's wages. Moreover, while it is standard to assume positive selection in the labour market (i.e. those with a higher wage potential are more likely to work), it is also plausible to see negative selection among women, where those with a higher wage potential also have a relatively high reservation wage and are therefore less likely to work.

The literature uses several methods to address this issue. Blau and Beller (1988), for instance, and more recently Mulligan and Rubinstein (2008), use a standard Heckman twostep selectivity bias correction. The Heckman (1979) method requires some arbitrary exclusion restrictions, i.e. it requires finding a variable that explains selection into the labour market, while being orthogonal to wages. Blau and Beller (1988) rely on individuals' non-labour income, a dummy for whether the individual is over 62 (and therefore entitled to early social security benefits), and the number of family members 18-64 years of age, while Mulligan and Rubinstein (2008) include the number of children 0-6 years of age interacted with marital status. ${ }^{5}$ Another way to approach selection is to estimate bounds on the wage distribution. Blundell et al. (2007) use theoretical restrictions to deliver informative bounds on the distribution of wages, assuming essentially that the selection is positive.

Finally, the most commonly used method - and the one applied in our analysis - is to impute wages based on observed characteristics, and when panel data is available, on wage observations in previous years (see, e.g. Neal and Johnson, 1996; Johnson et al., 2000; Neal, 2004; Blau and Kahn, 2006; Olivetti and Petrangolo, 2008). In particular, the main approach in these studies is to only make an assumption about whether the unobserved

${ }^{5}$ Several studies point out that the results from estimating a selection model are very sensitive to the modelling assumptions, see, e.g. Bar et al. (2015) and Huber and Melly (2015). 
wage is above or below the median. The main advantage of this approach is that it requires neither assumptions on the actual level of the missing wage observations nor any arbitrary exclusion restrictions.

Neal (2004) uses imputation techniques to estimate the wage gap between white and black women in the US, noting that on average black and white women select differently into work. The average young black woman who does not participate in the labour market is a single mother receiving government aid, while the average young white woman is a married mother receiving support from a working spouse. If women who work are negatively selected, i.e. are of lower ability on average than those who do not work, then the wage variable may underestimate the educational returns to education. On the other hand, if women who choose not to work are of higher ability on average than those who work, then the wage variable may overestimate the returns to education.

For women who have no observed wages between 1988 and 1992, Neal (2004) assumes that those who receive government aid, who have no postsecondary education and who receive no spousal support have wages below the median. In contrast, those with at least a high school education and who receive "substantial" income support from their spouse are assumed to be positioned above the median in the wage distribution. ${ }^{6}$ When looking at males, Neal (2004) assumes that all males who do not work over the entire period have low wages.

Blau and Kahn (2006) follow similar imputation rules and assume that those with at least a college degree and at least eight years of labour market experience have high wages, and that those with less than a high school degree and less than eight years' experience in

\footnotetext{
${ }^{6}$ Neal (2004) assumes women receive substantial spousal support if their husbands' wages place them above the $90^{\text {th }}$ (or alternatively $75^{\text {th }}$ ) percentile in the personal income distribution for 20-35-year-old males of the same race.
} 
the labour market receive wages that are below their gender-specific median wage. For those never observed working, Olivetti and Petrangolo (2008) apply a probability model to assign individuals wages either below or above the median. They use education and labour market experience to fit a probability model and then use the predicted probability as sampling weights. They use panel data sets for several countries to evaluate different imputation rules, namely by: (a) assigning low wages for those who are not working, (b) assigning low wages for those who are unemployed, (c) assigning low wages to those with less than a secondary education and less than 10 years of labour market experience, (d) assigning low wages for those who have partners who are at the bottom of the income distribution and (e) using previous wage observations. They then apply rule (c) to those who still have missing wage observations. In the US data, rule (b) appears to be most successful in imputing correct values relative to the median and rule (e) also performs relatively well.

Our analysis compares estimates when imputing wages based on previous surveys, using Neal's (2004) method, and when we assume that those who are unemployed have wage offers below the median (cf. Olivetti and Petrangolo, 2008).

Table 2, Column 1 lists the wage observations from the 2000 NLSY79 survey and shows that women have a substantially higher share of missing values among whites and Hispanics (while males have a higher share among blacks), while white males have the lowest share of missing observations $(16 \%)$ and Hispanic females the highest $(27 \%)$. In order to reduce selection into the wage analysis we execute the following three exercises. 
Rule a: As was the case with the education variable and the weights, we exploit the 1996 and 1998 survey to obtain information on wages for those with missing values in the 2000 survey. More specifically, when wages are missing in the 2000 survey, we use 1996 and/or 1998 observations to predict earnings in the 2000 survey. $^{7}$ This step decreases the share of missing values substantially (Table 2, Column 2), which now ranges from 3\% to $11 \%$.

Rule b: For those who still have missing observations after implementation of Rule $a$, we follow the wage imputation suggested by Neal (2004), who also uses NLSY79 surveys in his analysis. We impute arbitrarily low wages $(1$ dollar) for those with no postsecondary education, no spousal support and those who received government aid for at least 12 months in the last three years; and arbitrarily high wages (30 dollars) for those with at least a high school education and who reported spousal income that placed their spouse in the $19^{\text {th }}$ percentile in the personal income distribution in their age and race group. Under this rule, the share of missing observations ranges from $2 \%$ to $6 \%$ (Table 2, Column 3).

Rule c: For those who still have missing observations after implementation of Rule $a$, we follow Olivetti and Petrangolo (2008) and assign a wage of 1 dollar per hour to those who report they are unemployed. Assigning a low salary to those who are unemployed has only a marginal impact on the share of missing observations, which now ranges ranges from 3\% to $9 \%$ (Table 2, Column 4).

We apply Rule a first since exploiting wages in previous years when a panel is available is a standard practice in the literature. Rule $b$ takes advantage of the information available in the NLSY and provides interesting comparison as it allows people to select out of the labour market because of high reservation wages. Finally, Olivetti and Petrangolo (2008) compare

\footnotetext{
${ }^{7}$ Using the actual wage observations from the 1996 and 1998 waves yields very similar results.
} 
various imputation techniques and find that in the US, data assigning low wages to the unemployed (i.e. Rule c) was the technique that performed best when they compared their imputed wages to wage observations in other waves of the survey.

\section{$5 \quad$ Empirical analysis and results}

Before turning to Lang and Manove's (2011) signalling model, it is of value to empirically check for the presence of gender differences in education and ability. Table 3 tests the gender differences in college completion rates and further breaks the results down across income levels. The results show significant gender gaps in college completion rates among whites and blacks, i.e. $2.8 \%$ higher completion rates for white women compared to white men and a 5.6\% gender difference for blacks. The gender difference is most pronounced for medium income families (4.4\% for whites and $9.5 \%$ for blacks). For Hispanics however, the gender difference is non-significant.

Table 4 similarly examines gender differences in AFQT scores (ability) across both race and income levels. The results are presented separately for the mean and the standard deviations of AFQT scores. In line with arguments made by Becker et al. (2010), who study gender differences in the distribution of non-cognitive skills, there is not a significant gender difference in the means, except for Hispanics (where the mean AFQT is higher for males), but the standard deviation is significantly higher among men for all groups except for those from high-income households.

As illustrated in Figure 1, while the AFQT distribution is significantly different between whites and blacks, the contrast between men and women is not as stark. This suggests that statistical discrimination based on differences in expected abilities is unlikely to drive the gender differences in educational attainment among blacks and whites, which is the story 
for racial differences in educational attainment in Arcidiacono et al. (2010). ${ }^{8}$ Hispanics is the only group where we find significant gender differences in the AFQT scores, but it is also the only group where we do not find significant differences in educational attainment. It is possible that the gender gap in wages among Hispanics is partly explained by statistical discrimination and differences in expected abilities, but it does not appear to cause gender differences in college completion rates (cf. Table 3).

We next apply the LM model to study how gender discrimination may lead women to signal their productivity through higher education levels than men given the same level of ability. The model is originally designed to study race discrimination, but as argued in section 3 we should expect to see similar results when looking at the difference between men and women's educational decisions, namely that given their ability women obtain higher levels of education than men.

We proceed to present the empirical results of fitting the LM race discrimination model to genders by evaluating across genders the relationships between (i) education and ability (Table 5); (ii) wages and education (Table 6); and (iii) wages and ability (Table 7).

\subsection{Education and ability}

The LM model of signalling and discrimination applied to genders predicts education has a signalling value for females, particularly at low and intermediate levels of ability. This means that women have an increased incentive to obtain education at low (except the very lowest) and intermediate levels of ability. It follows from Corollary 1, parts (i) and (ii), that

\footnotetext{
8 They argue that there is statistical discrimination because the ability distribution differs between whites and blacks - and if ability is unobserved then expected ability is higher for whites. This contrasts the LM model, where the difference in educational attainment stems from the assumption that the ability of some workers (here female workers) is less observable, which is why employers put more weight on education for those workers.
} 
women's educational level as a function of ability (AFQT scores) is more concave than men's, and from Corollary 1, part (ii), that the educational level should be similar at the extremes of the ability distribution.

Figure 2 graphically explores these predictions by presenting the smoothed relationship between education and AFQT test scores by gender and race/ethnicity. Women's college completion rates are higher, until at approximately one and a half standard deviations above the mean AFQT score, where the men catch up. This is consistent with Corollary 1. For blacks the level of schooling is similar at the bottom of the ability distribution but diverges with higher AFQT scores. For Hispanics, women have higher levels of education at the intermediate levels of ability, while men have more education at the extremes of the distribution. Overall, these results therefore lend partial support to the LM model. However, as exact statements are more difficult to extract from the figure, we instead turn to a more complete statistical analysis.

To statistically investigate whether the signalling hypothesis is supported by the data Lang and Manove (2011) estimate the following specification (although they estimate it in the context of race not gender):

$$
\begin{aligned}
\text { Education }_{i}=\alpha_{0} & +\beta_{\text {AFQT }} \text { AFQT }_{i}+\beta_{\text {AFQT2 }} \text { AFQT }_{i}^{2}+\beta_{\text {female } \text { Female }_{i}} \\
& +\beta_{\text {female }, A F Q T \text { Female }_{i} \times A F Q T_{i}}+\beta_{\text {female, }, \text { AFQT2 }} \text { Female }_{i} \times A F Q T_{i}^{2}+\mathrm{Z}_{i} \Gamma+\varepsilon_{i}
\end{aligned}
$$

The dependent variable, Education , is the highest grade completed as measured in number of years it takes to obtain it. $\mathbf{Z}_{\mathbf{i}}$ is a vector that includes additional controls, i.e. family income distribution and parents' educational attainment. We also control for cohort fixed effects. The main predictions of the LM model applied to genders is, firstly, that $\beta_{\text {female,AFQT2 }}$ has a negative sign, i.e. that with more ability the educational attainment of women is 
increasing at a decreasing rate. This follows from Corollary 1, which implies that women's educational level as a function of ability (AFQT scores) is more concave than men's. And, secondly, the model predicts that the second order equation Female* $\left(a+b \mathrm{AFQT}+c \mathrm{AFQT}^{2}\right)$ equals zero for AFQT levels that are at the extremes (in which case men and women's educational levels are the same given their ability).

The results are reported in Table 5, where the estimates are consistent with the prediction of the signalling model, although primarily in the case of whites. In all specifications, $\beta_{\text {female,AFQT2 }}$ has the predicted negative sign, but it is only significant among whites and in one of the specifications for Hispanics. The $\beta_{\text {female }}$ coefficient is significant and positive for all ethnicity groups, indicating the gender difference in educational attainment when $A F Q T$ is at the mean (i.e. equals zero). This gender difference is in the range of 0.519 - 0.664 school years among whites (cf. Table 5, Columns 1-2). When excluding controls, the gender difference in education among whites is maximised at an AFQT score just above the mean, producing an educational gap of approximately 0.56 years. ${ }^{9}$ Including controls for parents' education and family income increases the maximised gender gap to 0.72 years of education. In comparison, when studying outcomes of blacks vs. whites, Lang and Manove (2011) find the gap between white and black men to be maximised slightly below the average ability score (when the standardised AFQT equals -0.16), producing a gap in educational attainment of 1.3 years across races, i.e. it is somewhat higher in magnitude. While the gender gap is smaller than the race gap, the results nevertheless suggest that with AFQT scores between -1.26 and 1.74 women obtain more schooling than

\footnotetext{
9 Searching for the maximum gender difference in education implies differentiating Equation (4) first with respect to (w.r.t.) Female and then w.r.t. $A F Q T$, which gives $0.112+2 \times(-0.236) \times A F Q T$. Finding the maximum by setting this equal to zero gives $A F Q T=0.24$. Thus, from Equation (4) differentiated w.r.t. to Female, the maximum gender gap in education becomes $0.519+0.112 \times 0.24-0.236 \times 0.24^{2}=0.56$ years of schooling.
} 
men of same ability (cf. Table 4 , bottom row), which covers $90 \%$ of whites' ability domain in the sample. ${ }^{10}$ This is consistent with Corollary 1, part (ii), i.e. that it is only at the extremes of the ability distribution, where the signalling value is zero, that men and women's educational attainment is equal given their ability. The coefficients for blacks and Hispanics are imprecisely estimated but point towards similar results (cf. Table 4, Columns 3-6).

\subsection{Wages and education}

The LM model further implies that women receive relatively low wages at the intermediate education levels (cf. Corollary 2). At low and high levels of schooling, however, the LM model predicts their wage rate to be closer to that of males. To examine this prediction the regression equation is:

$$
\begin{aligned}
& \log w_{i}=\alpha_{0}+\beta_{E d u c} E_{d u c}+\beta_{E_{\text {duc } 2}} E_{d u c_{i}^{2}}+\beta_{\text {female }} \text { Female }_{i} \\
& +\beta_{\text {female, Educ }} \text { Female }_{i} \times E^{2} d u c_{i}+\beta_{\text {female, Educ } 2} \text { Female }_{i} \times E^{2} d u c_{i}^{2}+\mathrm{Z}_{i} \Gamma+\varepsilon_{i}
\end{aligned}
$$

This equation follows the specification in Lang and Manove but is applied to gender

rather than race. The main prediction that follows from Corollary 2 is that $\beta_{\text {female,Educ }}$ has a positive sign. Since the results in Table 5 are imprecisely estimated for blacks and Hispanics, we focus on whites in the analysis. We use wages imputed by the various techniques described in section 3 , and for each imputation rule we estimate the model with and without additional controls. For Rules $b$ and $c$, we use median regressions, which means we only need to make assumptions about the positions of the imputed wages with respect

10 There are 6,584 observations of whites, 5,920 of whom have AFQT scores in the interval $-1.26-1.74$. This results in $5,925 / 6,584=90.0 \%$. 
to the median, and if the missing wages are imputed such that they place on the correct side of the median, then the median regression will retrieve the true parameters of interest.

The results in Table 6 are consistent with the predictions of the LM model as the relationship is relatively more convex for women (cf. a positive coefficient, $\beta_{\text {female,Educ } 2 \text {, }}$ ranging from 0.380 to 0.744 ), implying that the gender gap in wages increases at intermediate education levels. The table further reports (bottom row) the range of education level, where women have lower wages than men. As these intermediate levels of education in fact span the entire education domain in our sample, women receive lower wages than men across all observable education levels. The level of education where the gender gap is being maximised ranges from 9 years (Table 6, Column 4) to around 15 years (Columns 1 and 5) (the average amount of education among whites in the sample is 13.5 years). ${ }^{11}$ The main results, i.e. that male wages lie above female and that the difference is largest at the intermediate levels of education, are robust to the imputation method used. However the precision of the estimates are dependent on the specification. The lower bound where the male and female wage curves cross varies with the specification, and ranges from negative four years of education to seven years of education. However, less than $1 \%$ of people in the sample have less than seven years of education, so in all cases the lower bound excludes almost all women in the sample.

\subsection{Wages and ability}

Table 7 reports results from regressing earnings (log hourly wage) on ability (AFQT scores) without controlling for education. Based on the LM model women are expected to have

\footnotetext{
${ }^{11}$ This is obtained from differentiating equation (5) first w.r.t. Female and then w.r.t. Educ, which gives e.g. for column 1: $-0.149+2 \times(0.496) \times$ Edcuation / 100 using coefficient estimates from Column 2 in Table 5a. Setting this equal to zero gives Education $=15$.
} 
higher relative wages at the low (except the very lowest) and intermediate levels of ability (cf. Corollary 3). The log wage is regressed on the standardised AFQT score, its square, a female dummy, as well the corresponding interactions (i.e. similar to Equation (5), except with AFQT replacing education $(E d u c))$. It follows from Corollary 3 that $\beta_{\text {female,AFQT2 }}$ should have a negative sign. As in Table 6, we focus on whites and use imputed wages. For imputation Rules $b$ and $c$, we use median regressions.

In contrast to Table 6 , the results in Table 7 are sensitive to the specification used. $\beta_{\text {female,AFQT2 }}$ is non-significant under Rules $a$ and $c$, but when relying on Neal's (2004) method and making assumptions on both positive and negative selection into the labour market, the results are consistent with Corollary 3.

\subsection{Wages and the value of signalling among minorities}

The results in Equation (4) suggest that the LM model may not hold as strongly for minorities. The estimated coefficients have the correct sign but are not significant (except in Column 5). The theoretical literature defines both women and nonwhites as disadvantaged workers (see, e.g. Milgrom and Oster, 1987 and Phelps, 1972), and in the LM model it can be argued that for both of these groups education has a signalling value compared to white males. It is perhaps less clear how the mechanism works when comparing one disadvantaged group to another. If neither black females nor black males benefit from network effects, it is likely that both groups benefit from the signalling value of education, and gender in that case may not generate additional signalling value. A recent study by Nunley et al. (2014) looks at racial discrimination in the labour market, using an experimental design. While gender is not the main focus of the paper, they find that black 
males and black females are treated very similarly in the labour market and that the estimated difference between interview rates for black male applicants and black female applicants is virtually zero.

Table 8 presents the estimation of Equation (4), for minorities. For all specifications, except Column 6, $\beta_{\text {femaleEduc } 2}$ has a negative sign, whereas the main prediction (from Corollary 2 ) is that $\beta_{\text {female,Educ } 2}$ has a positive sign. In Table 9, we regress earnings on ability without controlling for education. The results for this estimation are consistent with Corollary 3, which predicts a negative sign of $\beta_{\text {female,AFQT2 } 2}$.

To sum up, the results for blacks are consistent with Corollary 1 but are not significant. The findings presented in Table 8 do not fit the model (i.e. Corollary 2). The results in Table 9 are consistent with Corollary 3 but are only significant when applying imputation Rule b. Overall, the results lend partial support to the LM model for blacks, but it is clear that further explanations are needed, in particular to explain the relationship between wages and education.

Similarly for Hispanics, the findings in Table 5 are consistent with Corollary 1 but are only significant when controls are not included. The results in Table 8 do not fit the model, i.e. Corollary 2 is not supported by the data, while the results in Table 9 are significant and consistent with Corollary 3.

In the case of Hispanics there is not a significant gender difference in college completion, as Table 3 shows. In contrast, there is a large gender gap among blacks. The literature is surprisingly silent about gender differences in college completion, gender differences in wages among minorities and the possible reasons for the differences. Combined, the results for minorities partially lend support to the LM model, although 
something besides the signalling value of education appears to contribute to the observed gender gap in wages and college completion.

\section{Concluding remarks}

Our paper examines how the educational choices across genders are associated with ability levels and how this relationship differs along the lines of race and ethnicity. Our findings are consistent with the LM model of statistical discrimination (in particular among whites), where education is more valuable to women due to signalling.

Discrimination against women in the labour market has unarguably decreased in the last few decades and this has been particularly evident in the labour market for educated workers, which has increased women's incentive to obtain a college education. There are several reasons why this might be the case. For example, ability may be more accurately revealed with increased levels of education, employers in the labour market for less educated workers may have more prejudice against female workers, and women may increasingly use education to signal their labour market attachment, since those who plan to spend more time out of the labour market have less incentive to spend their time and money on education.

In examining this, our findings lend support to the predictions of a signalling model in a labour market where employers' observations of women's productivity is noisier than that of men, but the precision of their observational abilities improves with increased education of the worker. The analysis shows that women on average obtain more education than men given their ability and that this is especially the case at the intermediate levels of the ability distribution, while schooling at the extreme ability levels is more similar. 
While the gender gap in educational attainment is most pronounced among racial minorities, the results in the paper primarily support a signalling story for whites, suggesting there are other factors contributing to the phenomenon for blacks and Hispanics. This calls for further research on the topic. It may be the case among minority groups that men face as much discrimination as women and in some cases even more, hence the gender difference in the incentive to signal ability through education may be negligible. Different labour market behaviour among white and black women may play a role in explaining the relatively larger gender gap among blacks. Women's labour market participation rates are higher among blacks than whites, and this is especially the case among women of higher ability and educational levels. 


\section{References}

Addison, John T., Orgul Ozturk, and Si Wang, 2014. "The Role of Gender and Sector in Promotion and Pay Over a Career," Journal of Human Capital 8(3): 280-317.

Allensworth, Elaine M., Paul T. Moore, Lauren Sartain and Marisa de la Torre, 2016. "The Educational Benefits of Attending Higher Performing Schools: Evidence from Chicago High Schools," Educational Evaluation and Policy Analysis, 38(3): 1-23

Altonji, Joseph G. and Rebecca M. Blank, 1999. "Race and Gender in the Labor Market," in O. Ashenfelter and D. Card (eds.) Handbook of Labor Economics, Edition 1, Volume 3, Chapter 48: 3143-3259.

Altonji, Joseph G. and Charles R. Pierret, 2001. "Employer Learning and Statistical Discrimination," The Quarterly Journal of Economics, 116(1): 313-350.

Arcidiacono, Peter, Patrick Bayer and Aurel Hizmo, 2010. "Beyond Signaling and Human Capital: Education and the Revelation of Ability," American Economic Journal: Applied Economics, 2(4): 76-104.

Autor, David, David Figlio, Krzysztof Karbownik, Jeffrey Roth and Melanie Wasserman, 2016. "School Quality and the Gender Gap in Educational Achievement," American Economic Review: Papers and Proceedings, 106(5): 289-295.

Bauer, Cara C. and Boris B. Baltes, 2002. "Reducing the Effects of Gender Stereotypes on Performance Evaluations," Sex Roles, 47(9/10): 465-476.

Becker, Gary S., William H. J. Hubbard, and Kevin M. Murphy, 2010. "Explaining the Worldwide Boom in Higher Education of Women," Journal of Human Capital, 4(3): 203241.

Becker, Gary S., William H. J. Hubbard, and Kevin M. Murphy, 2010b. "The Market for College Graduates and the Worldwide Boom in Higher Education of Women," American Economic Review, 100(2): 229-233.

Bertrand, Marianne, 2011. "New Perspectives on Gender." In Handbook of Labor Economics, Volume 4b, edited by Orley C. Ashenfelter and David Card, 1545-1592. Amsterdam: Elsevier, Ltd.

Bertrand, Marianne, Claudia Goldin, and Lawrence F. Katz, 2010. "Dynamics of the Gender Gap for Young Professionals in the Financial and Corporate Sectors," American Economic Journal: Applied Economics 2 (3): 228-55

Blau, Francine D. and Andrea H. Beller, 1988. "Trends in Earnings Differentials by Gender, 1971-1981," Industrial \& Labor Relations Review 41(4): 513-529.

Blau, Francine D. and Jed DeVaro, 2007. "New Evidence on Gender Differences in Promotion Rates: An Empirical Analysis of a Sample of New Hires," Industrial Relations 46(3): 511-550. 
Blau, Francine D. and Lawrence M. Kahn, 2006. "The U.S. Gender Pay Gap in the 1990s: Slowing Convergence," Industrial \& Labor Relations Review 60(1): 45-66.

Blau, Francine D. and Lawrence M. Kahn, 2007. "Changes in the Labor Supply Behavior of Married Women: 1980-2000," Journal of Labor Economics 25 (3): 393-438.

Blau, Francine D. and Lawrence M. Kahn, 2008. "Women's Work and Wages.” In The New Palgrave Dictionary of Economics, 2nd ed., edited by Steven N. Durlauf and Lawrence E. Blume, 762- 772. London: Palgrave Macmillan.

Blau, Francine D., and Lawrance M. Kahn, 2016. “The Gender Wage Gap: Extent, Trends, and Explanations” Working Paper 21913, NBER. Cambridge, MA.

Blundell, Richard, Amanda Gosling, Hidehiko Ichimura, and Costas Meghir, 2007 "Changes in the Distribution of Male and Female Wages Accounting for Employment Composition Using Bounds," Econometrica 75(2): 323-363.

Buchmann, Claudia and Thomas A. DiPrete, 2006. "The Growing Female Advantage in College Completion: The Role of Family Background and Academic Achievement," American Sociological Review 71(4): 515-541.

Card, David, Ana Rute Cardoso, and Patrick Kline, 2016. "Bargaining, Sorting, and the Gender Wage Gap: Quantifying the Impact of Firms on the Relative Pay of Women," Quarterly Journal of Economics 131(2): 633-686.

Chandra, Amitabh, 2000. "Labor-Market Dropouts and the Racial Wage Gap: 1940-1990," A.E.R. Papers and Proc. 90(May): 333-38.

Chiappori, Pierre-André, Murat Iyigun and Yoram Weiss, 2009. "Investment in Schooling and the Marriage Market," American Economic Review, 99(5): 1689-1713.

Cherlin, A. and Walters, P.B., 1981. “Trends in United States Men's and Women's Sex Role Attitudes," American Sociological Review, 46: 453-460.

Coate, Stephen and Glenn C. Loury, 1993. "Will Affirmative-Action Policies Eliminate Negative Stereotypes?” American Economic Review, 83(5): 1220-1240.

Cobb-Clark, Deborah A., 2001. "Getting Ahead: The Determinants of and Payoffs to Internal Promotion for Young U.S. Men and Women.” In Research in Labor Economics, vol. 20, edited by Solomon W. Polachek, 339-372. Amsterdam: Elsevier Science, JAI.

Correll, Shelley J., Stephen Benard, and In Paik, 2007. "Getting a Job: Is There a Motherhood Penalty?” American Journal of Sociology 112(5): 1297-1338.

Croson, Rachel and Uri Gneezy, 2009. "Gender Differences in Preferences," Journal of Economic Literature 47(2): 448-474.

DiPrete, Thomas A. and Claudia Buchmann, 2006. "Gender-Specific Trends in the Value of Education and the Emerging Gender Gap in College Completion," Demography, 43(1): 1-24. 
Gayle, George-Levi, Limor Golan, and Robert A. Miller, 2012. "Gender Differences in Executive Compensation and Job Mobility," Journal of Labor Economics 30 (4): 829-872.

Goldin, Claudia, 2006. “The Quiet Revolution That Transformed Women's Employment, Education, and Family," American Economic Review 96(2): 1-21.

Goldin, Claudia, 2014. “A Grand Convergence: Its Last Chapter," American Economic Review 104(4): 1091-1119.

Goldin, Claudia, Lawrence F. Katz and Ilyana Kuziemko, 2006. "The Homecoming of American College Women: The Reversal of the College Gender Gap," Journal of Economic Perspectives, 20(4): 133-156.

Goldin, Claudia and Cecilia Rouse, 2000. "Orchestrating Impartiality: The Impact of 'Blind' Auditions on Female Musicians," American Economic Review 90(4): 715-41.

Greene, Howard and Matthew Greene, 2004. "The Widening Gender Gap: Shifting Student Demographics Will Have Significant Impact on College Admissions," University Business, 7: 27-29.

Gronau, Reuben, 1974. "Wage Comparisons: A Selectivity Bias," Journal of Political Economy 82(6): 1119-43.

Hamner, W. Clay, Jay S. Kim, Lloyd Baird and William J. Bigoness, 1974. "Race and Sex as Determinants of Ratings by Potential Employers in a Simulated Work-Sampling Task," Journal of Applied Psychology, 59(6): 705-711.

Heckman, James J., 1979. "Sample Selection Bias as a Specification Error," Econometrica 47(1): 153-61.

Heckman, James J., Thomas M. Lyons, and Petra E. Todd, 2000. "Understanding BlackWhite Wage Differentials, 1960-1990," A.E.R. Papers and Proc. 90(May): 344-49.

Heckman, James J., Jora Stixrud and Sergio Urzua, 2006. "The Effects of Cognitive and Noncognitive Abilities on Labor Market Outcomes and Social Behavior," Journal of Labor Economics, 24(2): 411-482.

Heim, Bradley T., 2007. "The Incredible Shrinking Elasticities: Married Female Labor Supply, 1979-2003," Journal of Human Resources 42(4): 881-918.

Hellerstein, Judith K., Melissa McInerney and David Neumark, 2008. "Measuring the Importance of Labor Market Networks," IZA Discussion Paper 3570.

Hersch, Joni and W. Kip Viscusi, 1996. "Gender Differences in Promotions and Wages," Industrial Relations 35(4): 461-72.

Hubbard, William H.J., 2011, "The Phantom Gender Difference in the College Wage Premium," Journal of Human Resources, 46(3): 568-586. 
Jacob, Brian A., 2002. "Where the Boys Aren't: Non-cognitive Skills, Returns to School and the Gender Gap in Higher Education," Economics of Education Review, 21(6): 589598.

Johnson, William R., Yuichi Kitamura, and Derek Neal, 2000. "Evaluating a Simple Method for Estimating Black-White Gaps in Median Wages," American Economic Review Papers and Proceedings 90: 339-43.

King, Jacqueline E., 2000. "Gender Equity in Higher Education: Are Male Students at Disadvantage?" American Council on Education - Center for Policy Analysis.

King, Jacqueline E., 2006. "Gender Equity in Higher Education: 2006,” American Council on Education - Center for Policy Analysis.

Kurtulus, Fidan Ana and Donald Tomaskovic-Devey, 2012. "Do Female Top Managers Help Women to Advance? A Panel Study Using EEO-1 Records," The Annals of the American Academy of Political and Social Science 639(1): 173-197.

Lang, Kevin and Michael Manove, 2011. "Education and Labor Market Discrimination," American Economic Review, 101(4): 1467-1496.

Levanon, Asaf, Paula England, and Paul Allison, 2009. "Occupational Feminization and Pay: Assessing Causal Dynamics Using 1950-2000 U.S. Census Data,” Social Forces 88 (2): 865-981.

Lundberg, Shelly J. and Richard Startz, 1983. "Private Discrimination and Social Intervention in Competitive Labor Markets," American Economic Review, 73(3): 340-347.

McCue, Kristin. 1996. "Promotions and Wage Growth," Journal of Labor Economics 14 (2): 175-209.

Milgrom, Paul and Sharon Oster, 1987. "Job Discrimination, Market Forces, and the Invisibility Hypothesis," The Quarterly Journal of Economics 102(3): 435-476.

Montgomery, James D., 1991. "Social Networks and Labor Market Outcomes: Toward an Economic Analysis," American Economic Review 81(5): 1408-1418.

Moss-Racusin, Corinne A., John F. Dovidio, Victoria L. Brescoll, Mark J. Graham, and Jo Handelsman, 2012. "Science Faculty's Subtle Gender Biases Favor Male Students," Proceedings of the National Academy of Science (PNAS) 109(41): 16474-16479.

Mulligan, Casey B. and Yona Rubinstein, 2008. "Selection, Investment, and Women's Relative Wages," Quarterly Journal of Economics 123 (3): 1061-110.

Neal, Derek, 2004. “The Measured Black-White Gap among Women is Too Small," The Journal of Political Economy, 112(S1), Papers in Honor of Sherwin Rosen: A Supplement to Volume 112: 1-28.

Neal, Derek and William R. Johnson, 1996. "The Role of Premarket Factors in BlackWhite Wage Differences., Journal of Political Economy 194(5): 869-895. 
Neumark, David, Roy J. Blank and Kyle D. Van Nort, 1996. "Sex Discrimination in Restaurant Hiring: An Audit Study," The Quarterly Journal of Economics 111 (3): 915-41.

Noonan, Mary C., Mary E. Corcoran, and Paul Courant.,2005. "Pay Differences among the Highly Trained: Cohort Differences in the Sex Gap in Lawyers' Earnings," Social Forces 84(2): 853-72.

Olivetti, Claudia and Barbara Petrongolo, 2008. "Unequal Pay or Unequal Employment? A Cross- Country Analysis of Gender Gaps,” Journal of Labor Economics 26(4): 621-54.

Peña, Ximena, 2006. “Assortative Matching and the Education Gap,” Working Paper, 06-0612, Georgetown University, Department of Economics.

Phelps, Edmund S. 1972, "The Statistical Theory of Racism and Sexism," American Economic Review 62(4): 659-661.

Pinkston, Joshua C., 2003. "Screening Discrimination and the Determinants of Wages," Labour Economics 10(6): 643-658.

Reuben, Ernesto, Paola Sapienza, and Luigi Zingales. 2014. "How Stereotypes Impair Women's Careers in Science," PNAS 111(12): 4403-4408.

Santos-Pinto, Luís, 2012. "Labor Market Signaling and Self-Confidence: Wage Compression and the Gender Pay Gap," Journal of Labor Economics, 30(4): 873-914.

Spence, A. Michael, 1973. "Job Market Signaling," Quarterly Journal of Economics, 87(3): 35574.

Surmann, Amy T., 1997. "The Effects of Race, Weight, and Gender og Evaluations of Writing Competence," The Journal of Social Psychology, 137(2): 173-180.

Thornton, A., D.F. Alwin and D. Camburn, 1983. "Causes and Consequences of Sex-Role Attitudes and Attitude Change," American Sociological Review, 48: 211-227.

Thornton, A. and D. Freedman, 1979. "Changes in the Sex-Role Attitudes of Women, 1962-1977: Evidence from a Panel Study," American Sociological Review, 44: 832-842. 


\section{Figure 1. AFQT distribution}

This figure displays the density on the vertical axis and the standardised AFQT scores (i.e. ability) on the horizontal axis. Standardised AFQT scores are constructed such that the mean is zero and the standard deviation is one.

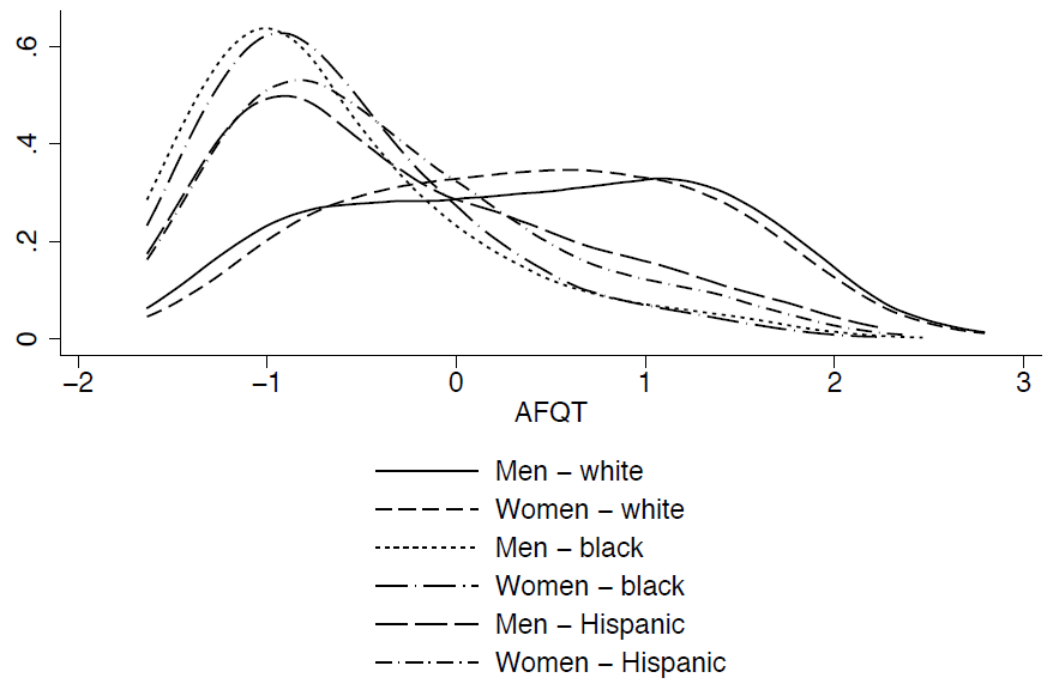




\section{Figure 2. Years of education vs. AFQT scores}

This figure displays years of education on the vertical axis and standardised AFQT scores (i.e. ability) on the horizontal axis. Standardised AFQT scores are constructed such that the mean is zero and the standard deviation is one.

\section{Whites}
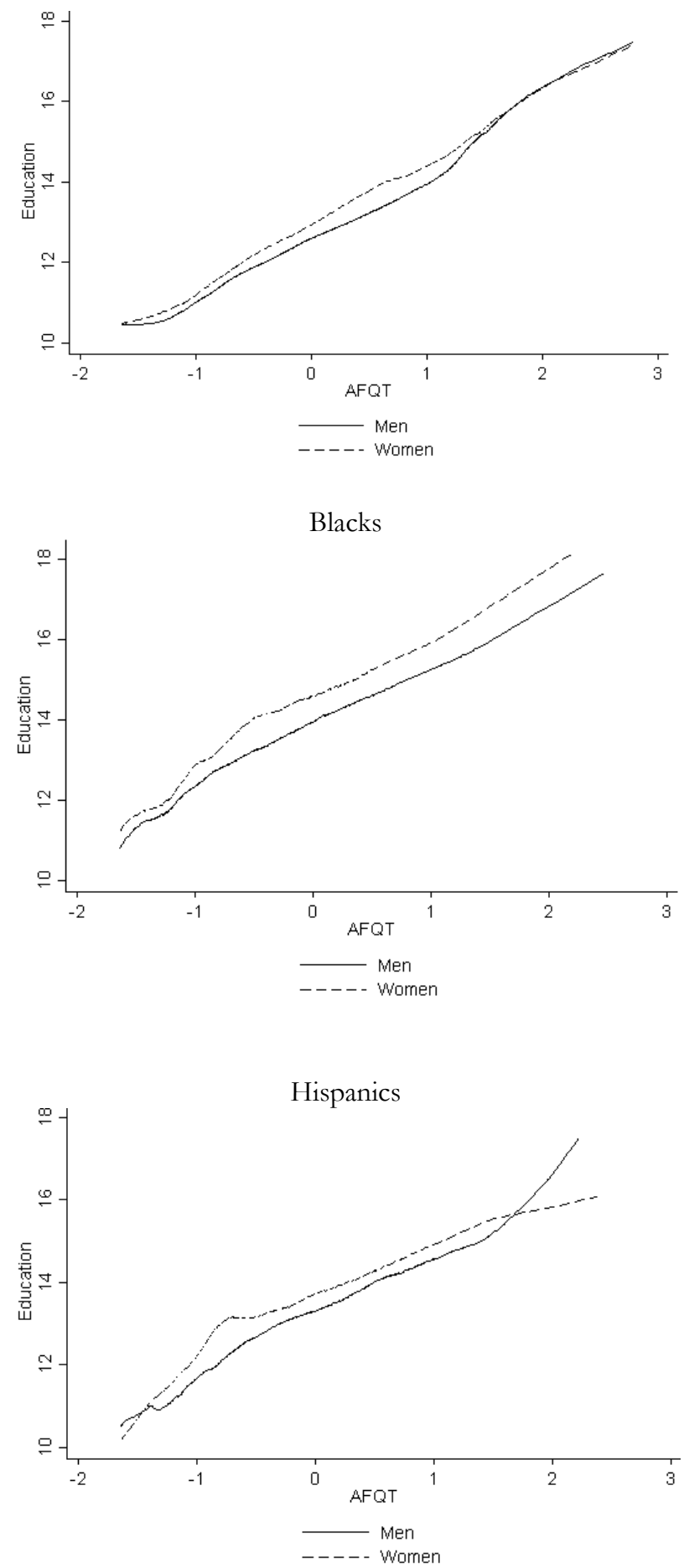
Table 1. Summary statistics

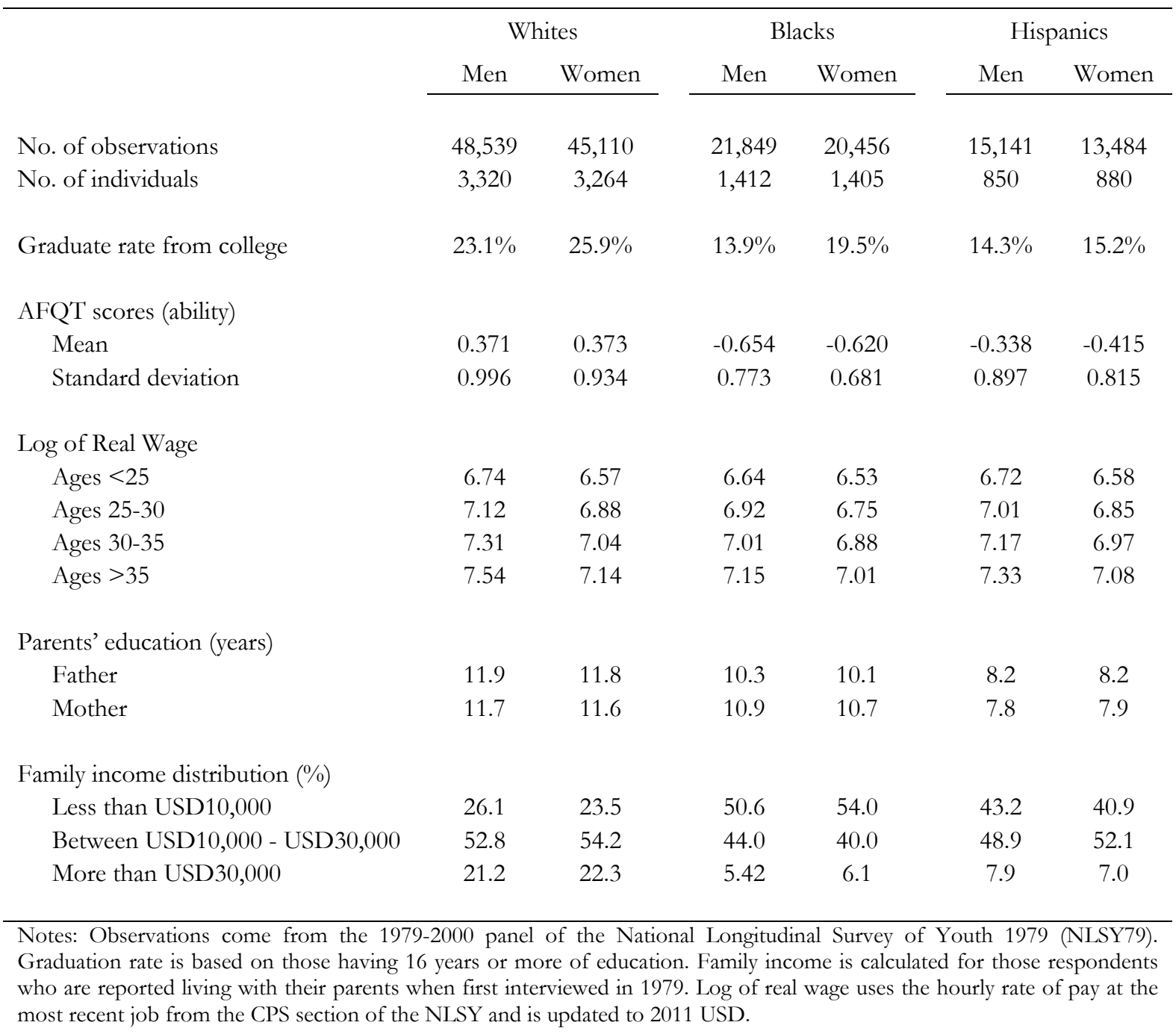

\section{Table 2. Missing wage observations (\%) by gender, race and imputation rule}

\begin{tabular}{lcccc}
\hline & No imputations & Rule a & Rule b & Rule c \\
\hline Men (white) & $16 \%$ & $3 \%$ & $2 \%$ & $3 \%$ \\
Women (white) & $22 \%$ & $8 \%$ & $6 \%$ & $7 \%$ \\
Men (black) & $25 \%$ & $8 \%$ & $5 \%$ & $7 \%$ \\
Women (black) & $21 \%$ & $8 \%$ & $4 \%$ & $7 \%$ \\
Men (Hispanic) & $19 \%$ & $4 \%$ & $3 \%$ & $4 \%$ \\
Women (Hispanic) & $27 \%$ & $11 \%$ & $6 \%$ & $9 \%$ \\
\hline
\end{tabular}

Notes: No Imputations: We only use the wages observed in the 2000 National Longitudinal Survey of Youth 1979

(NLSY79). Rule a: We use wages from two previous surveys (1996 and 1998) to impute wages in 2000. Rule b: We use Rule $a$ and then impute a wage of USD1.00 for all long-term aid recipients with no postsecondary education and no spousal support, and a wage of USD30.00 for those with at least 12 years of schooling and a spousal support that places the spouse above the $19^{\text {th }}$ percentile in their age and race group. Rule c: First we implement Rule $a$ and then assign a wage of USD1.00 to the unemployed. 
Table 3. Gender differences: College completion (male minus female)

\begin{tabular}{|c|c|c|c|}
\hline & Whites & Blacks & Hispanics \\
\hline All income levels & $\begin{array}{c}-.028^{* * *} \\
(.010)\end{array}$ & $\begin{array}{c}-.056^{* * *} \\
(.014)\end{array}$ & $\begin{array}{l}-.009 \\
(.016)\end{array}$ \\
\hline Low income family & $\begin{array}{l}-.036^{*} \\
(.020)\end{array}$ & $\begin{array}{l}-.017 \\
(.020)\end{array}$ & $\begin{array}{l}-.027 \\
(.025)\end{array}$ \\
\hline Medium income family & $\begin{array}{c}-.044^{* *} \\
(.020)\end{array}$ & $\begin{array}{c}-.095^{* * *} \\
(.029)\end{array}$ & $\begin{array}{c}.009 \\
(.030)\end{array}$ \\
\hline High income family & $\begin{array}{l}-.040 \\
(.035)\end{array}$ & $\begin{array}{l}-.176^{*} \\
(.092)\end{array}$ & $\begin{array}{c}.027 \\
(.092)\end{array}$ \\
\hline
\end{tabular}

Notes: College completion corresponds to having 16 years or more of education. Family income is calculated for those respondents who reported living with their parents when first interviewed in 1979.

Table 4. Gender differences: AFQT (male minus female)

\begin{tabular}{|c|c|c|}
\hline & Mean & St.dev. \\
\hline Whites & $\begin{array}{r}-.002 \\
(.024)\end{array}$ & $1.066^{* * *}$ \\
\hline Blacks & $\begin{array}{l}-.034 \\
(.027)\end{array}$ & $1.077 * * *$ \\
\hline Hispanics & $\begin{array}{l}.077^{*} \\
(.041)\end{array}$ & $1.101^{* * *}$ \\
\hline Low income family & $\begin{array}{l}-.044 \\
(.034)\end{array}$ & $1.099 * * *$ \\
\hline Medium family income & $\begin{array}{l}-.016 \\
(.034)\end{array}$ & $1.067 * * *$ \\
\hline High family income & $\begin{array}{l}.049 \\
(.058)\end{array}$ & 1.031 \\
\hline \multicolumn{3}{|c|}{$\begin{array}{l}\text { Notes: The first column presents the gender difference in mean } \\
\text { AFQT scores with standard errors in parentheses. *, ** and *** } \\
\text { indicate significance at the } 10,5 \text { and } 1 \text { percent levels of a two-tailed } \\
\text { t- test, allowing for unequal variances between groups. The second } \\
\text { column reports the ratio of men and women's AFQT score } \\
\text { standard deviations (st.dev.). *, ** and *** indicate significance at } \\
\text { the } 10,5 \text { and } 1 \text { percent levels of an F-test on whether the ratio is } \\
\text { significantly bigger than one. }\end{array}$} \\
\hline
\end{tabular}


Table 5. Education regressed on AFQT

\begin{tabular}{|c|c|c|c|c|c|c|}
\hline & \multicolumn{2}{|c|}{ White } & \multicolumn{2}{|c|}{ Black } & \multicolumn{2}{|c|}{ Hispanic } \\
\hline & (1) & (2) & (3) & (4) & (5) & (6) \\
\hline Constant & $\begin{array}{c}12.75^{* * *} \\
(.112)\end{array}$ & $\begin{array}{l}10.22^{* * *} \\
(.295)\end{array}$ & $\begin{array}{c}14.91 * * * \\
(.193)\end{array}$ & $\begin{array}{c}12.20 * * * \\
(.435)\end{array}$ & $\begin{array}{c}13.39 * * * \\
(.261)\end{array}$ & $\begin{array}{c}13.19 * * * \\
(.421)\end{array}$ \\
\hline AFQT & $\begin{array}{c}1.59 * * * \\
(.056)\end{array}$ & $\begin{array}{c}1.22^{* * *} \\
(.071)\end{array}$ & $\begin{array}{c}1.64^{* * *} \\
(.105)\end{array}$ & $\begin{array}{c}1.59^{* * *} \\
(.121)\end{array}$ & $\begin{array}{c}1.86^{* * *} \\
(.113)\end{array}$ & $\begin{array}{c}1.57 * * * \\
(.149)\end{array}$ \\
\hline $\mathrm{AFQT}^{2}$ & $\begin{array}{c}.199 * * * \\
(.046)\end{array}$ & $\begin{array}{l}.260^{* * *} \\
(.054)\end{array}$ & $\begin{array}{c}-.278^{* * *} \\
(. .098)\end{array}$ & $\begin{array}{l}-.229 * * \\
(.112)\end{array}$ & $\begin{array}{c}-.317^{* * *} \\
(.121)\end{array}$ & $\begin{array}{l}-.099 \\
(.138)\end{array}$ \\
\hline Female & $\begin{array}{l}.519 * * * \\
(.088)\end{array}$ & $\begin{array}{l}.664^{* * *} \\
(.107)\end{array}$ & $\begin{array}{l}.679 * * * \\
(.154)\end{array}$ & $\begin{array}{l}.607 * * * \\
(.189)\end{array}$ & $\begin{array}{l}.608^{* * *} \\
(.193)\end{array}$ & $\begin{array}{c}.673^{* * *} \\
(.240)\end{array}$ \\
\hline Female*AFQT & $\begin{array}{l}.112 \\
(.089)\end{array}$ & $\begin{array}{l}.128 \\
(.108)\end{array}$ & $\begin{array}{l}.151 \\
(.141)\end{array}$ & $\begin{array}{l}-.165 \\
(.164)\end{array}$ & $\begin{array}{l}-.030 \\
(.168)\end{array}$ & $\begin{array}{l}-.127 \\
(.199)\end{array}$ \\
\hline Female*AFQT $^{2}$ & $\begin{array}{c}-.236 * * * \\
(.069)\end{array}$ & $\begin{array}{c}-.272 * * * \\
(.084)\end{array}$ & $\begin{array}{l}-.141 \\
(.130)\end{array}$ & $\begin{array}{l}-.136 \\
(.157)\end{array}$ & $\begin{array}{c}-.367 * * \\
(.180)\end{array}$ & $\begin{array}{l}-.305 \\
(.210)\end{array}$ \\
\hline $\begin{array}{l}\text { Cohort fixed effect } \\
\text { Other controls }\end{array}$ & $\sqrt{ }$ & $\begin{array}{l}\sqrt{ } \\
\sqrt{ }\end{array}$ & $\sqrt{ }$ & $\begin{array}{l}\sqrt{ } \\
\sqrt{ }\end{array}$ & $\sqrt{ }$ & $\begin{array}{l}\sqrt{ } \\
\sqrt{ }\end{array}$ \\
\hline $\mathrm{N}$ & 4,013 & 2,459 & 2,457 & 1,275 & 1,525 & 860 \\
\hline $\begin{array}{l}\text { Ability level where } \\
\text { interaction equals } 0\end{array}$ & $-1.26,1.74$ & $-1.34,1.82$ & $-1.72,2.79$ & $-2.80,1.59$ & $-1.33,1.25$ & $-1.71,1.29$ \\
\hline
\end{tabular}


Table 6. Wages regressed on education (whites)

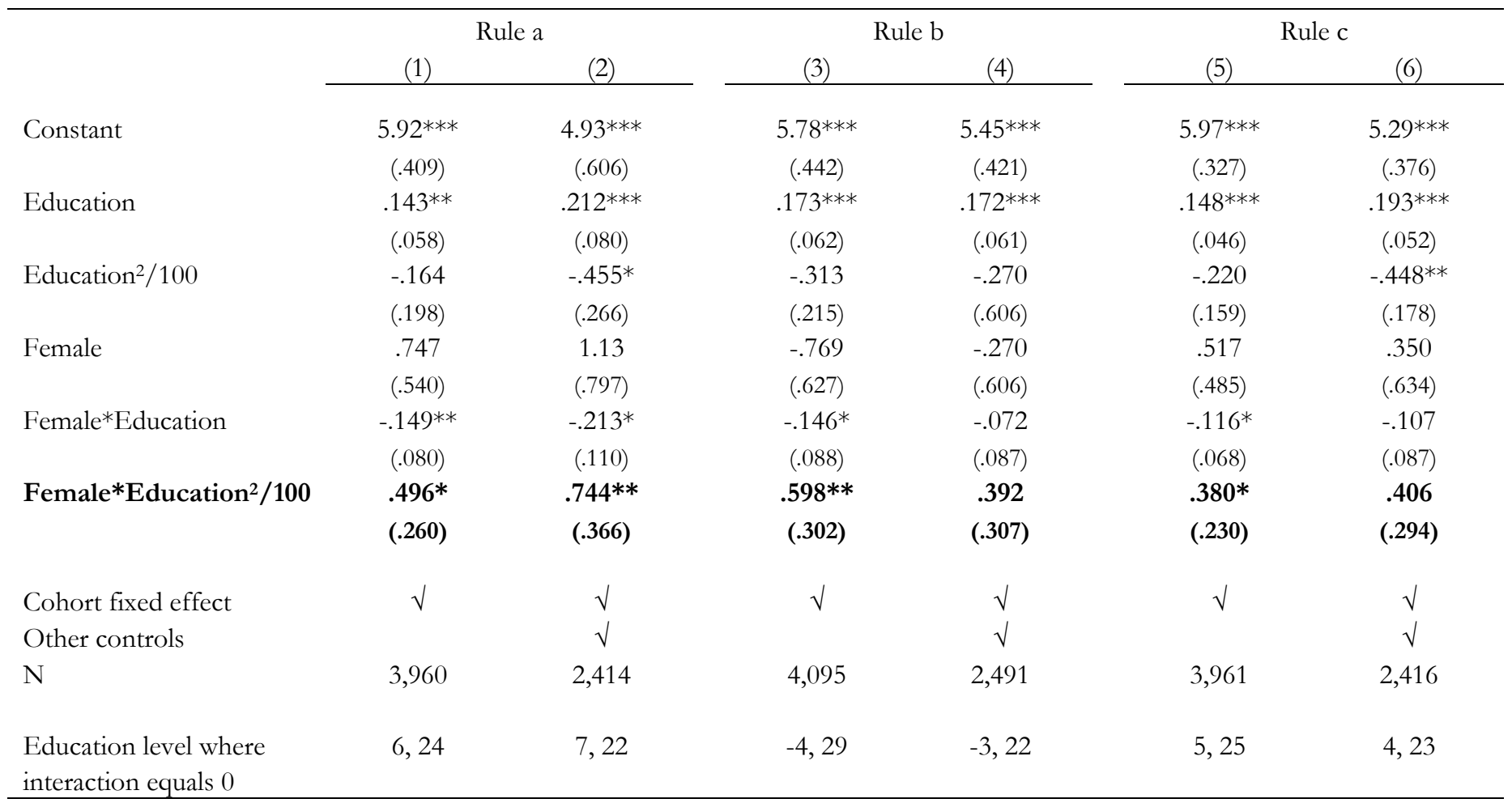

Notes: The dependent variable is a log of hourly wages. Robust standard errors are reported in parentheses. Other controls are family income and parents' educational level at the start of the sample period. Rule a: Uses wages from two previous survey years to find the predicted wages wage observations in 2000 are missing. Rule $b$ : We apply Rule $a$ and for remaining missing observations we do the following: for individuals not working we impute a wage of USD1.00 for all long-term aid recipients with no postsecondary education and no spousal support and a wage of USD30.00 for those with at least 12 years of education and spousal support that places the spouse above the $19^{\text {th }}$ percentile in the personal income distribution for men in that age and race/ethnicity group. Rule c. We apply Rule $a$ and then impute a wage of USD1.00 for the unemployed. For Rule $a$, the standard errors in parentheses are robust and clustered at the individual level. The reported estimates for Rules $b$ and $c$ come from a median regression with bootstrapped standard errors. The ability level at which interaction equals 0 solves the quadratic equation $a+b \mathrm{Educ}+c \mathrm{Educ}^{2}=0$, where $a$ is the female constant, $b$ is the coefficient on female*Education and $c$ is the coefficient on female*Education ${ }^{2}$, i.e. it indicates the ability level where wages are equal for men and women, other things being equal. 
Table 7. Wages regressed on AFQT (whites)

\begin{tabular}{|c|c|c|c|c|c|c|}
\hline & \multicolumn{2}{|c|}{ Rule a } & \multicolumn{2}{|c|}{ Rule b } & \multicolumn{2}{|c|}{ Rule c } \\
\hline & $(1)$ & (2) & (3) & (4) & (5) & (6) \\
\hline Constant & $\begin{array}{c}7.43 * * * \\
(.036)\end{array}$ & $\begin{array}{c}6.85^{* * *} \\
(.126)\end{array}$ & $\begin{array}{c}7.42^{* * *} \\
(.035)\end{array}$ & $\begin{array}{c}7.25^{* * *} \\
(.070)\end{array}$ & $\begin{array}{c}7.45^{* * *} \\
(.031)\end{array}$ & $\begin{array}{c}6.98^{* * *} \\
(.081)\end{array}$ \\
\hline AFQT & $\begin{array}{l}.274 * * * \\
(.023)\end{array}$ & $\begin{array}{l}.241 * * * \\
(.034)\end{array}$ & $\begin{array}{l}.222 * * * \\
(.021)\end{array}$ & $\begin{array}{c}.204^{* * *} \\
(.024)\end{array}$ & $\begin{array}{c}.209 * * * \\
(.017)\end{array}$ & $\begin{array}{l}.195^{* * *} \\
(.022)\end{array}$ \\
\hline $\mathrm{AFQT}^{2} / 100$ & $\begin{array}{l}-.278 \\
(1.65)\end{array}$ & $\begin{array}{l}-2.47 \\
(2.15)\end{array}$ & $\begin{array}{l}2.04 \\
(1.58)\end{array}$ & $\begin{array}{l}1.45 \\
(1.76)\end{array}$ & $\begin{array}{l}1.64 \\
(1.27)\end{array}$ & $\begin{array}{l}-.878 \\
(1.51)\end{array}$ \\
\hline Female & $\begin{array}{c}-.279 * * * \\
(.030)\end{array}$ & $\begin{array}{c}-.314 * * * \\
(.040)\end{array}$ & $\begin{array}{c}.135^{* * *} \\
(.028)\end{array}$ & $\begin{array}{c}.078^{* * *} \\
(.030)\end{array}$ & $\begin{array}{c}-.263 * * * \\
(.024)\end{array}$ & $\begin{array}{c}-.277 * * * \\
(.030)\end{array}$ \\
\hline Female*AFQT & $\begin{array}{c}-.073 * * \\
(.032)\end{array}$ & $\begin{array}{c}-.077^{*} \\
(.044)\end{array}$ & $\begin{array}{l}.070^{* *} \\
(.028)\end{array}$ & $\begin{array}{c}-.069 * * \\
(.032)\end{array}$ & $\begin{array}{l}.003 \\
(.025)\end{array}$ & $\begin{array}{l}.005 \\
(.034)\end{array}$ \\
\hline Female*AFQT ${ }^{2} / 100$ & $\begin{array}{l}1.68 \\
(2.38)\end{array}$ & $\begin{array}{c}3.62 \\
(3.23)\end{array}$ & $\begin{array}{c}-9.94 * * * \\
(2.13)\end{array}$ & $\begin{array}{c}-7.99 * * * \\
(2.38)\end{array}$ & $\begin{array}{l}-.969 \\
(1.86)\end{array}$ & $\begin{array}{l}-.486 \\
(2.36)\end{array}$ \\
\hline $\begin{array}{l}\text { Cohort fixed effect } \\
\text { Other controls }\end{array}$ & $\sqrt{ }$ & $\begin{array}{l}\sqrt{ } \\
\sqrt{ }\end{array}$ & $\sqrt{ }$ & $\begin{array}{l}\sqrt{ } \\
\sqrt{ }\end{array}$ & $\sqrt{ }$ & $\begin{array}{l}\sqrt{ } \\
\sqrt{ }\end{array}$ \\
\hline $\mathrm{N}$ & 3,786 & 2,328 & 3,915 & 2,403 & 3,787 & 2,330 \\
\hline $\begin{array}{l}\text { Ability level where } \\
\text { interaction equals } 0\end{array}$ & $-2.4,6.8$ & $-2.1,4.2$ & $-2.1,4.2$ & $-1.5,0.6$ & $\mathrm{~N} / \mathrm{A}$ & $\mathrm{N} / \mathrm{A}$ \\
\hline
\end{tabular}

Notes: The dependent variable is a log of hourly wages. Robust standard errors are reported in parentheses. Other controls are family income and parents' educational level at the start of the sample period. Rule $a$ : Uses wages from two previous survey years to find the predicted wages when wage observations in 2000 are missing. Rule b: We apply Rule $a$ and for remaining missing observations we do the following: for individuals not working we impute a wage of USD1.00 for all long-term aid recipients with no postsecondary education and no spousal support and a wage of USD30.00 for those with at least 12 years of education and spousal support that places the spouse above the $19^{\text {th }}$ percentile in the personal income distribution for men in that age and race/ethnicity group. Rule $c$. We apply Rule $a$ and then impute a wage of USD1.00 for the unemployed. For Rule $a$, the standard errors in parentheses are robust and clustered at the individual level. The reported estimates for Rules $b$ and $c$ come from a median regression with bootstrapped standard errors. The ability level at which interaction equals 0 solves the quadratic equation $a+b \mathrm{AFQT}+c \mathrm{AFQT}^{2}=0$, where $a$ is the female constant, $b$ is the coefficient on female*AFQT and $c$ is the coefficient on female*AFQT ${ }^{2}$, i.e. it indicates the ability level where wages are equal for men and women, other things being equal. There are no numbers reported for Rule $c$ because women's wages are below those of men in all cases (i.e. never equal). In other words the wage curve for women never crosses that of men. Under Rule a the coefficient on $\mathrm{AFQT}^{2}$ has a positive sign, i.e. the curve is convex and the wages lie below the wages of men between the ability levels in this table. 
Table 8. Wages regressed on education (blacks and Hispanics)

\begin{tabular}{|c|c|c|c|c|c|c|}
\hline & \multicolumn{3}{|c|}{ Blacks } & \multicolumn{3}{|c|}{ Hispanics } \\
\hline & Rule a & Rule b & Rule c & Rule a & Rule b & Rule c \\
\hline Constant & $\begin{array}{c}6.68^{* * *} \\
(.615)\end{array}$ & $\begin{array}{c}5.73 * * * \\
(.418)\end{array}$ & $\begin{array}{c}7.33^{* * * *} \\
(.461)\end{array}$ & $\begin{array}{c}7.27 * * * \\
(.256)\end{array}$ & $\begin{array}{c}6.95^{* * *} \\
(.255)\end{array}$ & $\begin{array}{c}6.46^{* * *} \\
(.115)\end{array}$ \\
\hline Education & $\begin{array}{l}-.012 \\
(.090)\end{array}$ & $\begin{array}{l}.130^{* *} \\
(.061)\end{array}$ & $\begin{array}{l}-.073 \\
(.067)\end{array}$ & $\begin{array}{l}-.058 \\
(.040)\end{array}$ & $\begin{array}{l}.001 \\
(.039)\end{array}$ & $\begin{array}{c}.084 * * * \\
(.010)\end{array}$ \\
\hline Educ. $^{2} / 100$ & $\begin{array}{c}.399 * * * \\
(.321)\end{array}$ & $\begin{array}{c}-.137 * * * \\
(.219)\end{array}$ & $\begin{array}{l}.538^{* *} \\
(.238)\end{array}$ & $\begin{array}{c}.504 * * * \\
(.158)\end{array}$ & $\begin{array}{l}.277^{*} \\
(.154)\end{array}$ & $\begin{array}{c}-.849 * * * \\
(.097)\end{array}$ \\
\hline Female & $\begin{array}{l}-1.00 \\
(.816)\end{array}$ & $\begin{array}{c}-2.31 * * * \\
(.642)\end{array}$ & $\begin{array}{c}-1.85^{* * *} \\
(.660)\end{array}$ & $\begin{array}{c}-1.26^{* * *} \\
(.326)\end{array}$ & $\begin{array}{c}-1.14 * * * \\
(.340)\end{array}$ & $\begin{array}{c}-.300^{* * *} \\
(.153)\end{array}$ \\
\hline Female*Educ & $\begin{array}{c}.133 \\
(.117)\end{array}$ & $\begin{array}{c}.297 * * * \\
(.019)\end{array}$ & $\begin{array}{l}.216 * * \\
(.095)\end{array}$ & $\begin{array}{c}.159 * * * \\
(.051)\end{array}$ & $\begin{array}{c}.158^{* * *} \\
(.053)\end{array}$ & $\begin{array}{c}.009 \\
(.014)\end{array}$ \\
\hline Female*Educ ${ }^{2} / 100$ & $\begin{array}{l}-.519 \\
(.413)\end{array}$ & $\begin{array}{c}-.966 * * * \\
(.330)\end{array}$ & $\begin{array}{c}-.678 * * * \\
(.333)\end{array}$ & $\begin{array}{c}-.587 * * * \\
(.203)\end{array}$ & $\begin{array}{c}-.587 * * * \\
(.204)\end{array}$ & $\begin{array}{c}.005 \\
(.014)\end{array}$ \\
\hline Cohort fixed effect & $\sqrt{ }$ & $\sqrt{ }$ & $\sqrt{ }$ & $\sqrt{ }$ & $\sqrt{ }$ & $\sqrt{ }$ \\
\hline $\mathrm{N}$ & 2,334 & 2,466 & 2,336 & 1,507 & 1,583 & 1,516 \\
\hline $\begin{array}{l}\text { Education level where } \\
\text { interaction equals } 0\end{array}$ & $\mathrm{~N} / \mathrm{A}$ & $\mathrm{N} / \mathrm{A}$ & $\mathrm{N} / \mathrm{A}$ & $\mathrm{N} / \mathrm{A}$ & $\mathrm{N} / \mathrm{A}$ & $-209,29$ \\
\hline
\end{tabular}

Notes: The dependent variable is a log of hourly wages. Robust standard errors are reported in parentheses.

Other controls are family income and parents' educational level at the start of the sample period. Rule a: Uses wages from two previous survey years to find the predicted wages when wage observations in 2000 are missing. Rule b: We apply Rule $a$ and for remaining missing observations we do the following: for individuals not working we impute a wage of USD1.00 for all long-term aid recipients with no postsecondary education and no spousal support and a wage of USD30.00 for those with at least 12 years of education and spousal support that places the spouse above the $19^{\text {th }}$ percentile in the personal income distribution for men in that age and race/ethnicity group. Rule $c$. We apply Rule $a$, and then impute a wage of USD1.00 for the unemployed. For Rule $a$, the standard errors in parentheses are robust and clustered at the individual level. The reported estimates for Rules $b$ and $c$ come from a median regression with bootstrapped standard errors. The ability level at which interaction equals 0 solves the quadratic equation $a+b \mathrm{Educ}+c \mathrm{Educ}^{2}=0$, where $a$ is the female constant, $b$ is the coefficient on female*Educ and $c$ is the coefficient on female*Educ ${ }^{2}$, i.e. it indicates the ability level where wages are equal for men and women, other things being equal. There are no numbers reported for Columns (1)-(5) because women's wages are below those of men in all cases (never equal), i.e. the wage curve for women never crosses that of men. 
Table 9. Wages regressed on AFQT - Blacks and Hispanics

\begin{tabular}{|c|c|c|c|c|c|c|}
\hline & \multicolumn{3}{|c|}{ Blacks } & \multicolumn{3}{|c|}{ Hispanics } \\
\hline & Rule a & Rule b & Rule c & Rule a & Rule b & Rule c \\
\hline Constant & $\begin{array}{c}7.51 * * * \\
(.040)\end{array}$ & $\begin{array}{l}7.36 * * * \\
(.053)\end{array}$ & $\begin{array}{l}7.46^{* * *} \\
(.054)\end{array}$ & $\begin{array}{c}7.65^{* * *} \\
(.061)\end{array}$ & $\begin{array}{c}7.69^{* * *} \\
(.060)\end{array}$ & $\begin{array}{c}7.62 * * * \\
(.051)\end{array}$ \\
\hline AFQT & $\begin{array}{c}.303^{* * *} \\
(.034)\end{array}$ & $\begin{array}{l}.266^{* * *} \\
(.031)\end{array}$ & $\begin{array}{c}.250^{* * *} \\
(.028)\end{array}$ & $\begin{array}{l}.258^{* * *} \\
(.031)\end{array}$ & $\begin{array}{c}.244^{* * *} \\
(.026)\end{array}$ & $\begin{array}{l}.233 * * * \\
(.023)\end{array}$ \\
\hline $\mathrm{AFQT}^{2} / 100$ & $\begin{array}{l}-.815 \\
(3.24)\end{array}$ & $\begin{array}{l}-1.98 \\
(3.02)\end{array}$ & $\begin{array}{l}-.966 \\
(2.73)\end{array}$ & $\begin{array}{l}.359 \\
(3.30)\end{array}$ & $\begin{array}{l}-1.81 \\
(2.73)\end{array}$ & $\begin{array}{l}-1.59 \\
(2.37)\end{array}$ \\
\hline Female & $\begin{array}{c}-.134 * * * \\
(.046)\end{array}$ & $\begin{array}{l}.060 \\
(.048)\end{array}$ & $\begin{array}{c}-.099 * * \\
(.045)\end{array}$ & $\begin{array}{l}-.079 * \\
(.046)\end{array}$ & $\begin{array}{l}-.020 \\
(.047)\end{array}$ & $\begin{array}{c}-.121 * * * \\
(.042)\end{array}$ \\
\hline Female*AFQT & $\begin{array}{l}-.005 \\
(.043)\end{array}$ & $\begin{array}{l}.066 \\
(.045)\end{array}$ & $\begin{array}{l}.065 \\
(.042)\end{array}$ & $\begin{array}{l}.050 \\
(.041)\end{array}$ & $\begin{array}{l}.086^{* *} \\
(.037)\end{array}$ & $\begin{array}{l}.159 \\
(.034)\end{array}$ \\
\hline Female*AFQT $^{2} / 100$ & $\begin{array}{l}-2.45 \\
(4.07)\end{array}$ & $\begin{array}{c}-10.7 * * \\
(4.29)\end{array}$ & $\begin{array}{l}-2.59 \\
(4.00)\end{array}$ & $\begin{array}{c}-11.0 * * * \\
(4.28)\end{array}$ & $\begin{array}{c}-8.71 * * \\
(3.83)\end{array}$ & $\begin{array}{c}-9.03 * * * \\
(3.45)\end{array}$ \\
\hline Cohort fixed effect & $\sqrt{ }$ & $\sqrt{ }$ & $\sqrt{ }$ & $\sqrt{ }$ & $\sqrt{ }$ & $\sqrt{ }$ \\
\hline $\mathrm{N}$ & 2,251 & 2,378 & 2,255 & 1,405 & 1,479 & 1,411 \\
\hline $\begin{array}{l}\text { Ability level where } \\
\text { interaction equals } 0\end{array}$ & $\mathrm{~N} / \mathrm{A}$ & $-0.5,1.1$ & $\mathrm{~N} / \mathrm{A}$ & $\mathrm{N} / \mathrm{A}$ & $0.4,0.6$ & $\mathrm{~N} / \mathrm{A}$ \\
\hline
\end{tabular}

Notes: The dependent variable is a log of hourly wages. Robust standard errors are reported in parentheses.

Other controls are family income and parents' educational level at the start of the sample period. Rule a: Uses wages from two previous survey years to find the predicted wages when wage observations in 2000 are missing. Rule $b$ : We apply Rule $a$ and for remaining missing observations we do the following: for individuals not working we impute a wage of USD1.00 for all long-term aid recipients with no postsecondary education and no spousal support and a wage of USD30.00 for those with at least 12 years of education and spousal support that places the spouse above the $19^{\text {th }}$ percentile in the personal income distribution for men in that age and race/ethnicity group. Rule $c$. We apply Rule $a$ and then impute a wage of USD1.00 for the unemployed. For Rule $a$, the standard errors in parentheses are robust and clustered at the individual level. The reported estimates for Rules $b$ and $c$ come from a median regression with bootstrapped standard errors. The ability level at which interaction equals 0 solves the quadratic equation $a+b \mathrm{AFQT}+c \mathrm{AFQT}{ }^{2}=0$, where $a$ is the female constant, $b$ is the coefficient on female*AFQT and $c$ is the coefficient on female*AFQT ${ }^{2}$, i.e. it indicates the ability level where wages are equal for men and women, other things being equal. There are no numbers reported for Columns (1), (3), (4) and (6) because women's wages are below those of men in all cases (never equal), i.e. the wage curve for women never crosses that of men. 